\title{
Transversal Competency Level of Engineering Graduates Dictated by Euro- pean Industry
}

\section{Mariana Leandro Cruz, Delft University of Technology}

Mariana Leandro Cruz received the BSc and MSc degrees in Biomedical Engineering from the Instituto Superior Técnico, University of Lisbon. She is currently developing the $\mathrm{PhD}$ in engineering education at the Delft University of Technology, Faculty of Aerospace Engineering in the Netherlands. Her research interests include engineering education, competencies, competency measurement, and course development.

\section{Dr. Gillian N. Saunders-Smits, Delft University of Technology}

Gillian Saunders-Smits is Senior Lecturer and Passionate Engineering Education Researcher and Curriculum Developer at the Faculty of Aerospace Engineering of TU Delft in the Netherlands. She teaches Research Methodologies to all Master students, runs a MOOC on the Introduction to Aerospace Structures and Materials and has previously taught Mechanics, Flight mechanics, and Design Projects and has served as Project Education Coordinator in the Bachelor and Master Track Coordinator for Aerospace Structures and Materials track and was the initiator of the successful online education program at Aerospace Engineering. She has overseen many curriculum innovation projects, most recently the overhaul of the MSc. track in Aerospace Structures and Materials. She is currently the principal investigator for TU Delft in the European Erasmus+ PREFER project on the Professional Roles and Employability of Future Engineers and serves on the Steering Committee of the European Association of Engineering Education (SEFI). 


\title{
Transversal Competency Level of Engineering Graduates Dictated by European Industry
}

\begin{abstract}
The importance of which transversal competencies, a collective term for non-technical competencies such as problem-solving and communication skills, are required for student success in the labor market has been studied. There is no doubt that students need transversal competencies for professional practice. However, little is known about the specific competency level that graduates should hold after completion of their Bachelor or Master in Engineering.

To investigate graduates' competency levels, this article reports on the design, development, and results of an industry questionnaire, which studies the perception of industry representatives in Europe of the competency levels that Bachelor and Master engineering graduates should hold after graduation.
\end{abstract}

A total of 28 representatives who work in the engineering industry and who recruit or work with recently graduated engineers responded. Industry representatives were given a list of 36 competencies and were asked to select the most important competencies and the competency level they perceive students should have after completion of their Bachelor and Master degree for each.

Significant differences were found between the required competency levels for Bachelor and Master graduates. Industry representatives perceived that Master graduates require mostly advance level (as opposed to a lower level for bachelor graduates) for competencies such as risk tolerance, problem-solving, listening skills, writing skills, interdisciplinary thinking, strengths/weaknesses awareness, and actively seeking learning. These findings were unaffected by years of work experience of the industry respondents or their company size.

The findings of this study help higher education institutions, employers and lecturers to stimulate the development of competencies required by industry. More specifically, they will be used as a starting point for developing and implementing curriculum elements aimed at enhancing competency levels of students at a Dutch university of technology and its European partners in the European project funding this research.

Keywords Transversal competency level, preparing for practice, engineering education, questionnaire

\section{INTRODUCTION}

The globalization and the great change in technology of the 90 s have posed different demands on the engineering profession. This shift has resulted in the industry seeking graduates equipped with both technical and non-technical competencies [I]. In this study, the latter is named transversal competencies and defined as "skills, values, and attitudes that are required for learners' holistic development and for learners to become capable of adapting to change" [2]. These competencies comprise for example communication skills, creativity, problem-solving, and reflective thinking. 
Although accreditation bodies [3] stimulate the integration of transversal competencies in engineering education curricula and higher education institutions emphasized their incorporation into the curriculum to increase students' employability [4], there is still a gap between industry requirements and graduates readiness to the labor market $[5,6]$. Several studies investigated the industry [7, 8] or academic perspective [9] on which transversal competencies engineering students should possess to successfully enter the labor market. In the systematic review of Passow and Passow [4], planning and time management, problem-solving, communication and teamwork were identified as highly important by engineers. Identified as less, but still important, were ethics, lifelong learning, taking initiative, thinking creatively, and focusing on goals. Does this mean that engineering students need more teamwork skills than lifelong learning skills? Or do students need to finish their educational program with an advanced level mastery of lifelong learning and an expert level mastery of teamwork? These questions raise the need to not just investigate the importance of the competencies but also of the competency levels required by industry from Bachelor and Master graduates. For this research, engineers working in the European engineering industry who recruit or work with recent graduates were approached.

The following research questions are addressed in this paper:

1. Which transversal competencies does industry require for engineering graduates?

2. Which competency levels does industry require at Bachelor (BSc.) and Master (MSc.) graduations?

3. Is there a difference between BSc. and MSc. competency level?

4. Are there differences in competency levels between respondents' experience?

5. Are there differences in competency levels between respondents' company size?

The findings of this pilot study reveal some interesting preliminary insights which are used to reflect back on the design of courses and course elements (i.e. in-course activities, small workshops and standalone courses) that can address curriculum deficiencies.

\section{Definition and characterization of a set of transversal competencies}

To reduce the skills mismatch in the field of engineering and improve employability, a consortium consisting of three European Universities, three European Engineering Industries and several other Industry and Engineering stakeholders in Belgium, Ireland and the Netherlands, set up a collaborative education and research project, that is funded through the European Union's Erasmus+ Knowledge Alliance. The project, called PREFER (Professional Roles and Employability of Future EngineeRs), [10] has as one of its aims to design innovative curriculum elements that focus on a particular set of transversal competencies and implement these elements in the curricula of participating universities. For this purpose, five transversal competencies (Entrepreneurial, Innovation, Communication, Teamwork, and Lifelong Learning) were selected, defined and characterized based on an existing framework of the Siemens company in the Netherlands (See Appendix A). A rubric for each of the selected competencies was generated with four descriptive levels (Appendix B). This rubric was chosen as a starting point for competency evaluation as part of the industry collaboration stipulated by the European Union in Knowledge Alliances. Considering Siemens is a worldwide employer of engineers and this competency framework 
is used to assess personal development throughout Siemens, it was deemed a good starting point for a pilot study in the context of the project deliverables and the accompanying timeframe. In an ideal situation it would have been great to create such a rubric based on input from a broad variety of industry but that was not possible in the scope and timeframe of this project. That being said, the rubric from Siemens has not been taken as the absolute truth but formed a starting point for further refinement of the rubric. The competencies and the levels of the rubric were subsequently revised by academic experts in order to confirm that the model was suitable for academia.

The main advantage of this rubric compared to existing rubrics reported in the literature is that it is based on a competency framework used by the labor market. A second plus is that it is a 4-point Likert scale with descriptive scales (Level 0 - Absent, level I - Basic, level 2 - Advanced, and level 3 - Expert). The fact that these scales are described in rubrics form reduces the subjectivity from the responses, although a full elimination of all types of bias may be a Utopian quest.

In this study, this rubric is used to investigate the perception of European industry representatives of the competency levels that BSc. and MSc. engineering students should hold after graduation.

\section{Data collection and survey structuring}

A questionnaire was disseminated from January to April 2018 among representatives of European engineering industries and engineering associations (such as engineers, managers, and HR representatives) who hire or work with recently graduated engineers. For this research ethical permission was sought and granted from the university's Ethics Committee. The sampling strategy chosen in this research was snowball sampling, i.e. the authors identified individuals with the characteristics of interest within the project partnership and these informed and included others. Also, the personal network of the main lecturers involved was drawn upon. A total of 28 representatives of different engineering disciplines (e.g. 38\% of Mechanical, Aeronautical \& Manufacturing Engineering, 35\% of Engineering \& Technology, I I.6\% of Material Science, 7.7\% of Chemical Engineering and Life Sciences, and $7.7 \%$ of Petrochemical \& Energy) based mainly in Northern Europe responded to the questionnaire and gave permission to be part of this research with some 70 people being approached overall The response was not very high, which was to be expected given the length of the questionnaire and the time required to fill it in. Several industry contacts also declined as they indicated feeling overburdened by the many questionnaires they are asked to fill out these days, not just for education but for many other stakeholders also.

The first part of the questionnaire contained questions about the information of the industry representatives including company name, job position, and working experience. In the Netherlands, working experience is divided into 3 categories: junior (Jr.) from 0 to 3 years, medior (Mr.) from 4 to 10 years and senior (Sr.) more than 10 years. In the data set, there are $3 \mathrm{Jr}$., $8 \mathrm{Mr}$., and $17 \mathrm{Sr}$. respondents. Because of the low response rates of the junior representatives, Jr. and Mr. were combined in the analysis of the response. Using the company name, it was possible to divide respondents into small and medium-sized 
enterprises (SME) - less than 250 employees, and large enterprises (LE) - more than 250 employees. In the data, there are 10 SME and 18 LE.

The second part of the questionnaire was aimed at selecting the most important competencies for engineering graduates. For this purpose, industry representatives indicated the three most important competencies (within the five competency categories:

Entrepreneurial, Innovation, Communication, Teamwork, and Lifelong Learning, Appendix) they felt that engineering students at Master level should hold when they graduate. The top 3 competencies were ranked by the industry representatives and a score ranging from 3 to I was assigned to the top 3. Finally, the standardized sum of scores was drawn.

In the third part of the questionnaire, industry representatives indicated in the rubric the level (Level 0 - Absent, level I - Basic, level 2 - Advanced, and level 3 - Expert) for 36 competencies that they perceive BSc. and MSc. engineering students should have at graduation.

\section{Data analysis}

Data from the questionnaires were entered and analyzed in IBM SPSS Statistics 25. A Wilcoxon signed-rank test was carried out to evaluate the differences between the two experimental conditions (BSc. and MSc.) for each competency.

To compare the competency level at BSc. and MSc. graduation between experiences (Jr. \& Mr. and Sr.) or company sizes (SME and LE) a Mann-Whitney U-test was used.

Significant differences were considered for $p$-values smaller than 0.05 . The effect size, $r$, was

calculated using: $r=\frac{Z}{\sqrt{N}}[\mathrm{II}]$. Values of $r=.0 \mathrm{I}, .30$, and .5 refer to a small, medium, and large effect, respectively [II].

\section{RESULTS AND DISCUSSION}

In this section, answers to the research questions will be addressed. The data was acquired from a questionnaire delivered to European professionals who hire or work with recent engineering graduates.

\section{Important and essential competencies}

Previous studies by Saunders-Smits [7], Passow and Passow [8], and Beagon and Bowe [7-9] tried to understand which competencies engineering graduates need for successful professional practice. They end up with results illustrating that all the competencies are important because they are above the middle of a five-point Likert scale. Therefore, the alternative used in this paper was competency ranking to differentiate further. In Figure $I$ it is illustrated that some competencies, highly ranked by industry professionals (marked with an asterisk), are deemed more essential for a graduate's professional practice than others.

\section{Competency levels at BSc. and MSc. graduation}

This research also intended to find out which competency levels industry requires from BSc. and MSc. graduates respectively, or in other words which competency levels do students need when looking for a job after completing a BSc. and a MSc. degree (Table I). 
As is to be expected and predicted by the authors and confirmed by a Wilcoxon signedranked test, MSc. graduates require higher competency levels compared to BSc. graduates (Table I, $\mathrm{P}<.0 \mathrm{I}$ ). Besides relying only on the statistical significance, the authors calculated the effect size, a standardized measure to quantify the effect in the present sample [II]. Large effect sizes $(r>0.5$ [I I], Table I) were found for all competencies indicating the importance of the findings or in other words that the effect of the test is meaningful within the research context.

Comparing the top 10 most required competencies from Figure I (marked with an asterisk) with the competencies which require expert level (level 3, Table I), it is observed that a recent graduate must not hold expert-level mastery in all of these essential competencies (e.g. project management, engagement in teamwork, autonomous work, curious for innovation, engagement in teamwork, technology benchmarking, value/cost consciousness and business acumen) selected by the industry representatives. And conversely, industry representatives perceive that students after obtaining their MSc. should have an expert level for writing skills, but this competency was not deemed highly important by those same representatives. Consistent with the findings in previous studies [7-9], problem-solving is ranked top as the most important competency. Also, expert level mastery is required from MSc. graduates for this competency. Similarly, actively seeking learning and strengths and weaknesses awareness are also in the top 10 of most important competencies and also require expert level mastery. From the findings, it can be seen that MSc. graduates also need to hold expert-level mastery in listening skills (Table I). This result confirms previous findings by Trevelyan [6], who showed that young engineers are more likely to spend time listening than speaking. Listening skills as part of communication were also considered an essential skill in the study of Beagon and Bowe [9].

Furthermore, mastery levels of BSc. students in teamwork and communication competencies are higher than the mastery levels required for BSc. students in innovation and entrepreneurial competencies (Table I). This is not surprising. Early jobs often require working in teams and learning from each other. This requires more skills than just engagement in teamwork and oral and written communication. This result can be compared with the findings in a complementary study conducted by Hundley and Brown [12] who investigated the top attributes of student upon graduation from high school, college or university and early-career engineering professionals (with up to 5-years of work experience) [12]. They found that early-career professionals were expected to possess higher proficiency levels for the attribute possesses the ability to think both critically and creatively than students upon university graduation. For MSc. graduates, besides reaching expert level in communication and teamwork, industry requires higher levels of mastery in innovation competencies (Table I).

Comparing the ten highest means of required mastery at BSc and MSc levels (grey cells in Table I), it can be observed that they share seven competencies. These seven competencies: time management, risk tolerance, listening skills, writing skills, interdisciplinary thinking, strength and weakness awareness, and actively seeking learning are obviously competencies that must be addressed in both BSc. and MSc. engineering degrees. At the same time, similar attributes like shows initiative and demonstrates a willingness to learn and communicates effectively in $a$ 
variety different ways, methods and media were in the top 5 for both university graduates and engineering professionals in the study of Hundley and Brown [12].

Remarkably, English language skills, collaborative goal oriented and engagement in teamwork are only in the top 10 for BSc. students. Perhaps these are expected as mastered entities at master level, hence the emphasis shifts at the master level to different competencies being listed as most important.

Problem-solving, critical thinking and presentation skills are only in the top 10 for MSc. graduates. This is perhaps indicative of what industry expects of MSc. graduates: more independent abilities and the ability to orally present your findings appropriately by yourself.

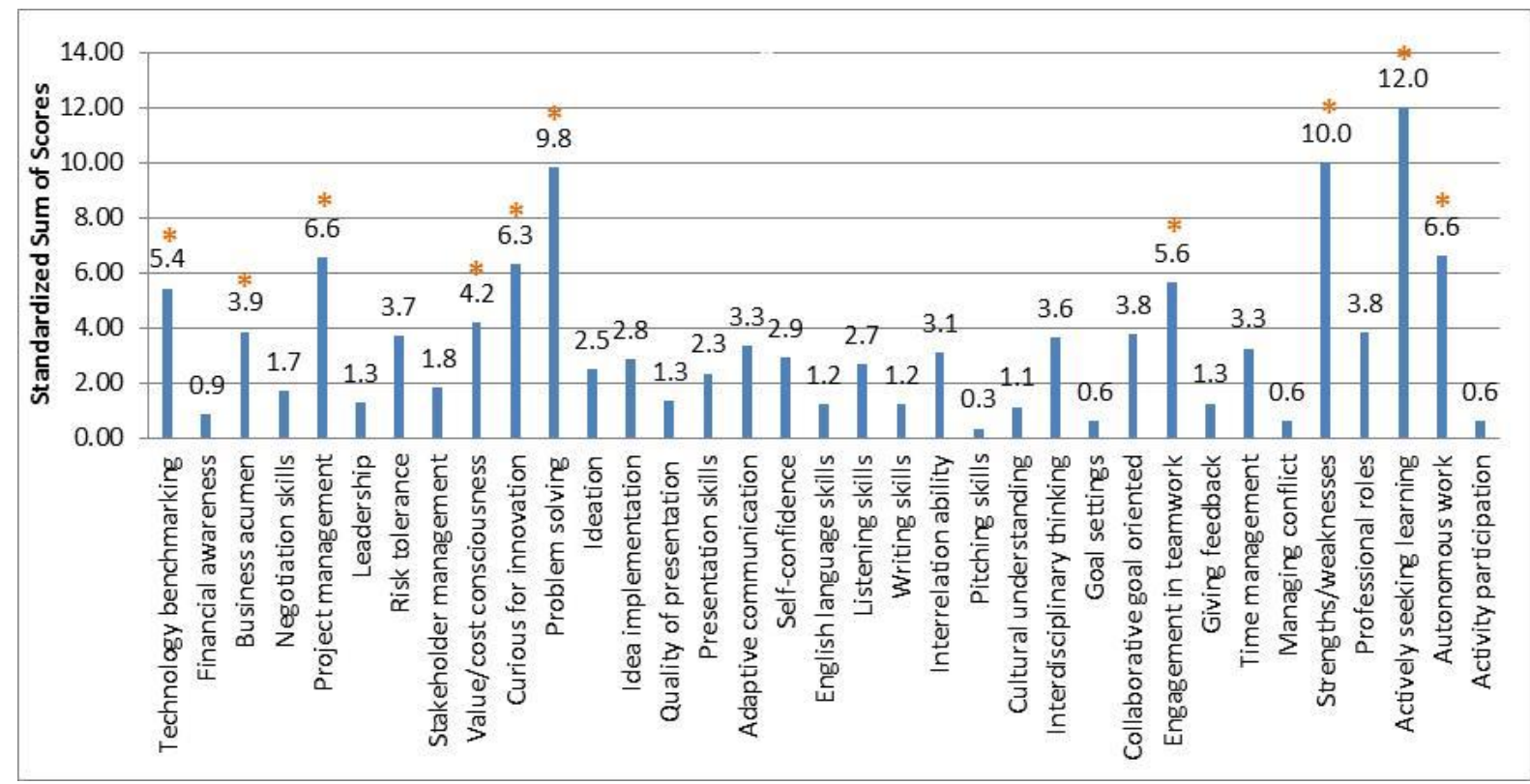

Figure I - Competencies and their respective standardized sum of scores of importance obtained from industry representatives. Asterisks indicate the ten highest scores i.e. the most essential competencies for MSc.

graduates according to the industry.

Table I - Differences between BSc. and MSc. competency levels. z-score: z, p-value: $\mathrm{p}$ (significant level p < .05), and effect size: $r$. Grey cells represent the ten highest mean competency levels for BSc and MSc. and asterisks indicate the competencies which require advanced level mastery (Median = 3).

\begin{tabular}{|c|c|c|c|c|c|c|c|c|c|c|}
\hline & \multirow{3}{*}{ Competencies } & \multicolumn{9}{|c|}{ Wilcoxon signed-rank test } \\
\hline & & \multicolumn{2}{|c|}{ Median } & \multicolumn{2}{|c|}{ Mean } & \multicolumn{2}{|c|}{ SD } & \multirow{2}{*}{$\mathbf{z}$} & \multirow[b]{2}{*}{$\mathbf{p}$} & \multirow{2}{*}{$\mathbf{r}$} \\
\hline & & BSc. & MSc. & BSc. & MSc. & BSc. & MSc. & & & \\
\hline \multirow{7}{*}{ 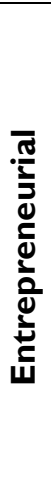 } & Technology benchmarking & I & 2 & 1.04 & 1.89 & .53 & .50 & -4.60 & $<.01$ & .9 \\
\hline & Financial awareness & I & I & .58 & 1.36 & .58 & .56 & -4.38 & $<.01$ & .9 \\
\hline & Business acumen & 1 & 2 & 1.08 & 1.82 & .63 & .86 & -3.88 & $<.01$ & .8 \\
\hline & Negotiation skills & 1 & 1.5 & .65 & 1.46 & 69 & 69 & -4.30 & $<.01$ & .8 \\
\hline & Project management & I & 2 & 1.31 & 2.25 & .55 & .65 & -4.73 & $<.01$ & .9 \\
\hline & Leadership & 1 & 2 & .81 & 1.61 & .69 & .83 & -4.58 & $<.01$ & .9 \\
\hline & Risk tolerance $*$ & 2 & 3 & 1.77 & 2.46 & .82 & .64 & -3.82 & $<.01$ & .7 \\
\hline
\end{tabular}




\begin{tabular}{|c|c|c|c|c|c|c|c|c|c|c|}
\hline \multirow{7}{*}{ 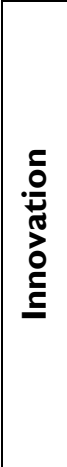 } & Stakeholder management & 1 & 2 & 1.12 & 1.89 & .59 & .57 & -4.38 & $<.01$ & .9 \\
\hline & Value/cost consciousness & I & 2 & 1.19 & 2.07 & .49 & .60 & -4.41 & $<.01$ & .9 \\
\hline & Curiosity for innovation & 1 & 2 & 1.38 & 2.14 & .57 & .45 & -4.47 & $<.01$ & .9 \\
\hline & Problem solving * & 2 & 3 & 1.62 & 2.57 & .64 & .57 & -4.13 & $<.01$ & .8 \\
\hline & Critical thinking & I & 2 & 1.46 & 2.43 & .51 & .50 & -4.73 & $<.01$ & .9 \\
\hline & Ideation & 1 & 2 & 1.04 & 2.07 & .60 & .60 & -4.51 & $<.01$ & .9 \\
\hline & Idea implementation & 1 & 2 & .81 & 1.64 & .63 & .62 & -4.38 & $<.01$ & .9 \\
\hline \multirow{9}{*}{ 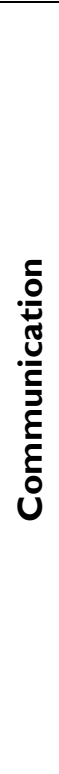 } & $\begin{array}{l}\text { Quality of presentation } \\
\text { method }\end{array}$ & 2 & 2 & 1.68 & 2.21 & .55 & .42 & -3.74 & $<.01$ & .7 \\
\hline & Presentation skills & 1 & 2 & 1.50 & 2.36 & .58 & .62 & -3.23 & $<.01$ & .6 \\
\hline & $\begin{array}{l}\text { Adaptive communication } \\
\text { style }\end{array}$ & 2 & 2 & 1.62 & 2.14 & .64 & .45 & -3.5 & $<.01$ & .7 \\
\hline & Self-confidence & 2 & 2 & 1.54 & 2.11 & .76 & .63 & -3.42 & $<.01$ & .7 \\
\hline & English language skills & 2 & 2 & 1.73 & 2.18 & .60 & .39 & -3.46 & $<.01$ & .7 \\
\hline & Listening skills & 2 & 2.5 & 2.00 & 2.46 & .63 & .58 & -3.46 & $<.01$ & .7 \\
\hline & Writing skills $*$ & 2 & 3 & 1.81 & 2.50 & .69 & .58 & -4.12 & $<.01$ & .8 \\
\hline & $\begin{array}{l}\text { Interconnection/interrelation } \\
\text { ability }\end{array}$ & 1 & 2 & 1.27 & 2.04 & .72 & .43 & -3.88 & $<.01$ & .8 \\
\hline & Pitching skills & 1 & 2 & 1.35 & 2.00 & .69 & .54 & -3.82 & $<.01$ & .7 \\
\hline \multirow{8}{*}{ 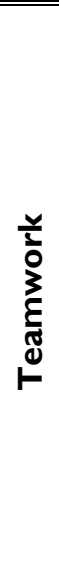 } & Cross-cultural understanding & 2 & 2 & 1.58 & 2.25 & .70 & .59 & -4.03 & $<.01$ & 0.8 \\
\hline & Interdisciplinary thinking * & 2 & 3 & 1.96 & 2.71 & .66 & .46 & -3.88 & $<.01$ & 0.8 \\
\hline & Goal settings & 2 & 2 & 1.62 & 2.29 & .50 & .46 & -4.24 & $<.01$ & 0.8 \\
\hline & Collaborative goal oriented & 2 & 2 & 1.77 & 2.14 & .43 & .45 & -3.16 & $<.01$ & 0.6 \\
\hline & Engagement in team work & 2 & 2 & 1.81 & 2.18 & .49 & .48 & -3.16 & $<.01$ & 0.6 \\
\hline & Giving constructive feedback & 1 & 2 & 1.58 & 2.11 & .64 & .57 & -3.74 & $<.01$ & 0.7 \\
\hline & Time management & 2 & 2 & 1.85 & 2.32 & .46 & .55 & -3.46 & $<.01$ & 0.7 \\
\hline & Managing conflict & 2 & 2 & 1.62 & 2.04 & .64 & .58 & -3.46 & $<.01$ & 0.7 \\
\hline \multirow{5}{*}{ 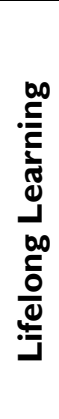 } & $\begin{array}{l}\text { Strengths and weaknesses } \\
\text { awareness * }\end{array}$ & 2 & 3 & 2.15 & 2.79 & .73 & .50 & -3.82 & $<.01$ & 0.7 \\
\hline & Professional role awareness & 1 & 2 & 1.42 & 2.11 & .58 & .69 & -4.15 & $<.01$ & 0.8 \\
\hline & Actively seeking learning $*$ & 2 & 3 & 1.88 & 2.64 & .65 & .56 & -4.30 & $<.01$ & 0.8 \\
\hline & Autonomous work & 2 & 2 & 1.50 & 2.11 & .58 & .57 & -4.00 & $<.01$ & 0.8 \\
\hline & $\begin{array}{l}\text { Non-credit activity } \\
\text { participation }\end{array}$ & 1 & 2 & 1.04 & 1.50 & .72 & .84 & -3.36 & $<.01$ & 0.7 \\
\hline
\end{tabular}




\section{Competency level differences between years of working experience}

The authors also researched whether the amount of work experience of the respondents effected their opinion on competency levels. A distinction was made between Jr. \& Mr. (less than 10 years of work experience) and $\mathrm{Sr}$. (more than 10 years of work experience). A Mann-Whitney U-test found no significant differences between respondents based on their years of work experience with regard to their opinion on competency levels of BSc. and MSc. graduates. Therefore, there is general agreement between less and more experienced industry representatives regarding the level of competencies of BSc. and MSc. graduates.

\section{Competency level differences between SME and large enterprises}

The same test was carried out to test whether the competency levels were different based on the respondents' company size (SME and LE). The results show that there is a significant difference between company size with regard to risk tolerance for BSc. graduates $(p<0.05)$. SME require students to have a higher level of mastery in risk tolerance $(M d n=2.5)$ than LE $(M d n=1.5)$. This in itself is not surprising as the size of these companies means that risks affect their everyday business more than larger companies who are likely more robust. Furthermore, no other significant differences were found for the other competencies and the company size. The findings show that SME and LE require similar levels of almost all the competencies for BSc. and MSc. graduates.

\section{Limitations of the study}

The low sample size $(N=28)$ of industry respondents in this study prevents validity and reliability measurements. It is the intention of the authors to create an online survey, to be will be administered over 2019 to scale up the pilot study and as a resulting effect of the increased number of responses address the validity and reliability analyses accordingly. Another limitation of this work is the reliance as a starting point on a rubric developed based on an existing unpublished framework used to measure the personal development engineers by Siemens. However, within the scope of the research presented, and by scaling up the pilot study, the authors feel they have done enough to negate any possible oversights.

\section{RECOMMENDATIONS FOR ENGINEERING CURRICULA}

The outcomes of this pilot study provide engineering educators with preliminary insights on what competency levels industry expects graduates to enter and perform successfully in the labor market. These outcomes may also inspire the field of engineering education to come up with curriculum adaptations to better match the needs of future employers and thus produce graduates with the desired competencies. To aid lecturers in this development, the authors make some preliminary observations and recommendations for engineering curricula in this section, that they feel may address some of the current mismatch.

\section{Teamwork}

In terms of teamwork, the authors worry, based on their own teaching experiences, that developing teamwork competencies by just putting students in teams is not enough. Students may be benefit from being explicitly mentored on how to manage time, tasks and 
responsibilities, and set common expectations and goals when working in groups. This way, they may improve on competencies such as time management, engagement in teamwork, collaborative goal oriented. In addition, because when working as engineers, they do not solve problems alone, students may benefit from working in different teams (i.e. background studies, culture) from the start so that they can learn to relate to and depend on others [14]. Research shows that this is best done with explicit instruction in interpersonal skills [15] and open discussions about differences in cultural behaviors and approaches to work in teams [I3].

\section{Communication}

The teaching of communication skills should perhaps not be limited to just being able to give oral presentations and write a written report at the end of a project Encouraging practices such as suggested in Leandro Cruz and Saunders-Smits [16] in which students experience a wide spectrum of ways to communicate, such as describing, listening, questioning, answering, and drawing. Next to that, engagement of students, for example by interviewing customers to understand their problems and needs, or by exposing students to non-technical/societal issues, would help students to develop other communication competencies that are currently often unaddressed, such as their sense of community and how to deal with nonengineering thinking and communication.

\section{Method of Delivery}

The authors also suggest that, in order for students to acquire and master competencies, curricula may also include learning activities that are varied in terms of learning tasks to satisfy students' diverse competency needs and that using student centered activities imposes responsibility and autonomy of students' learning [17].

Previous studies [17] showed that project-based learning improves communication, teamwork, understanding of professional practice. To also address innovation and creativity, ensure when designing project-based learning that assignments allow students the opportunity to produce real(istic) products or services (ideally with real clients) that trigger their creativity and innovation as well as their entrepreneurial abilities.

\section{Problem Solving}

It may also be worthwhile to consider exposing students to many different kinds of problems throughout their degree. Problems should be open-ended, ill-structured, ambiguous and complex, in which not only the technological answers need to be considered, but also nonengineering contextual factors/constraints such as costs, time, functionality, as it happens in real engineering life [14].

\section{Life Long Learning}

Although little evidence as yet exists on the effectiveness of discovery or guided learning [17], this inquiry-based approach may benefit students' actively seeking learning because students self-directly work to discover knowledge (without or with guidance) to answer questions, to solve problems or to explain observations. In addition, the authors feel that 
actively seeking learning as well as strengths and weaknesses awareness may be stimulated with the introduction of reflections in the curriculum, because they may support students to reflect on their strengths and weaknesses and consequently seek for learning to fulfill the needs [18].

\section{Industry Exposure}

Finally, to better prepare students for the industry we, as educators, should also considering whether students are sufficiently exposed to industry during their degree: Inform students about professional engineering roles and provide moments to experience them throughout courses. Involve students with industry from the start by inviting guest speakers from industry, with projects that require client interaction, and stimulating students going on industry internships [19].

\section{CONCLUSION}

The major difference between this research and previous studies is that it focuses not only on which transversal competencies industry requires graduates to have, but also on the competency level that BSc. and MSc. graduates need to successfully enter into the labor market. This study showed that competencies, including problem-solving, strengths and weaknesses awareness, and actively seeking learning, were considered very important and required expert-level mastery when a student obtains their Master. Competencies such as risk tolerance, listening skills, writing skills, interdisciplinary thinking, time management, strengths and weaknesses awareness, and actively seeking learning all require high mastery levels for both Bachelor and Master graduates with Master graduates being held to a higher level than Bachelor graduates. These show the necessity of addressing these competencies in engineering curricula.

When examining the background of the respondents, years of work experience of industry respondents were shown to have no influence on the desired competency levels of BSc. and MSc. Graduates, and only one competency level, risk tolerance, was found to be affected by the company size of the respondents. A number of recommendations are given in this paper to aid educators in teaching competencies in engineering education based on the results found.

In terms of further research, the pilot will now be expanded to a larger study involving more industry participants in order to get a deeper understanding of the skills gap. Also, current curriculum elements that have introduced over the past 20 years at the institution the authors work at will be evaluated for their effectiveness in teaching the competencies they set out to teach. Next to that, the authors will continue to develop learning activities for students specifically aimed to aid student in the development of competencies such as listening skills, time management, strengths and weaknesses awareness, and actively seeking learning and publish them as OpenCourseWare in order to continue to educate the engineers of tomorrow. 


\section{ACKNOWLEDGMENTS}

This work was funded by the Erasmus+ program of the European Union (grant agreement 575778-EPP-I-20 I6-I-BE-EPPKA2-KA) and is part of the PREFER project

(http://www.preferproject.eu/). The authors would like to acknowledge the EU for funding this project. The authors also would like to thank their project partners for their feedback and assistance with this study. Our final thanks go to all industry participants in this study, whose input is invaluable.

\section{REFERENCES}

[1] Shuman, L.J., M. Besterfield-Sacre, and J. McGourty, "The ABET "professional skills" Can they be taught? Can they be assessed?", Journal of Engineering Education Vol. 94, No. 1, 2005, pp. 41-55.

[2] Care, E., and Luo, Rebekah "Assessment of Transversal Competencies: Policy and Practice in the Asia-Pacific Region.", Paris, France: UNESCO, 2016.

[3] Engineering Accreditation Commission, Criteria for Accrediting Engineering Programs, Baltimore, 2000.

[4] Passow, H.J., and C.H. Passow, "What competencies should undergraduate engineering programs emphasize? A systematic review", Journal of Engineering Education Vol. 106, No. 3, 2017, pp. 475-526.

[5] Almi, N.E.A.M., N.A. Rahman, D. Purusothaman, and S. Sulaiman, "Software engineering education: The gap between industry's requirements and graduates' readiness", Computers \& Informatics (ISCI), 2011 IEEE Symposium on: IEEE, 2011, pp. 542-547.

[6] Trevelyan, J., "Mind the gaps: engineering education and practice", Proceedings of the 21st Annual Conference for the Australasian Association for Engineering Education, Sydney, Australia, 2010, pp. 383.

[7] Saunders-Smits, G.N., "The Secret of their Success: What factors determine the career success of an aerospace engineer trained in the Netherlands?", ASEE Annual Conference and Exposition, Portland, Oregon, 2005.

[8] Passow, H.J., and C.H. Passow, "Which ABET competencies do engineering graduates find most important in their work?", Journal of Engineering Education Vol. 101, No. 1, 2012, pp. 95-118.

[9] Beagon, U., Bowe, B., "The Academic Perspective: A study of academic's perceptions of the importance of professional skills in engineering programmes in Ireland", 46th SEFI Annual Conference, Conpenhagen, Denmark, 2018.

[10] Craps, S., Pinxten, M., Saunders-Smits, G. N., Leandro Cruz, M., Gaughan, K., and Langie, G., "Professional Roles and Employability of Future Engineers", 45th SEFI Annual Conference, Azores, Portugal, 2017.

[11] Field, A., Discovering Statistics Using SPSS, London, United Kingdom: SAGE publications, 2009.

[12] Hundley, S., and L.G. Brown, "The Attributes of a Global Engineer Project: Updates, Inputs, Faculty Devel-opment Considerations", ASEE International Forum, Atlanta, Georgia, 2013.

[13] Oakley, B., R.M. Felder, R. Brent, and I. Elhajj, "Turning student groups into effective teams", Journal of student centered learning Vol. 2, No. 1, 2004, pp. 9-34.

[14] Jonassen, D., J. Strobel, and C.B. Lee, "Everyday problem solving in engineering: Lessons for engineering educators", Journal of engineering education Vol. 95, No. 2, 2006, pp. 139-151. 
[15] Prince, M., "Does active learning work? A review of the research", Journal of engineering education Vol. 93, No. 3, 2004, pp. 223-231.

[16] Leandro Cruz, M., and G.N. Saunders-Smits, "Design and Implementation of New Communication and Lifelong Learning elements in a Master Engineering Course", 46th SEFI Annual Conference, 2018.

[17] Prince, M.J., and R.M. Felder, "Inductive teaching and learning methods: Definitions, comparisons, and research bases", Journal of engineering education Vol. 95, No. 2, 2006, pp. 123-138.

[18] Mann, K., J. Gordon, and A. MacLeod, "Reflection and reflective practice in health professions education: a systematic review", Advances in health sciences education Vol. 14, No. 4, 2009, pp. 595.

[19] Haag, S., E. Guilbeau, and W. Goble, "Assessing engineering internship efficacy: Industry's perception of student performance", International Journal of Engineering Education Vol. 22, No. 2, 2006, pp. 257. 


\section{Appendix A}

Definition and characterization of the five selected competencies.

\begin{tabular}{|c|c|c|}
\hline & Sub-competencies & Definition \\
\hline \multirow{7}{*}{ 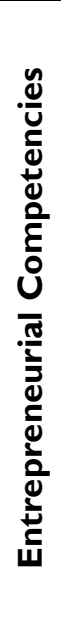 } & $\begin{array}{l}\text { Technology } \\
\text { benchmarking }\end{array}$ & $\begin{array}{l}\text { Demonstrates awareness of market drivers, emerging technologies, } \\
\text { competitions, pricing and customer needs, regulations and standards }\end{array}$ \\
\hline & Financial awareness & $\begin{array}{l}\text { Demonstrates awareness of financial capital (funding, cash flow, taxes, wages, } \\
\text { etc.) }\end{array}$ \\
\hline & Business acumen & $\begin{array}{l}\text { Identifies business opportunities and applies business modeling and problem } \\
\text { solving to implement strategic responses }\end{array}$ \\
\hline & Negotiation skills & $\begin{array}{l}\text { Demonstrates knowledge of negotiation methods and negotiates under risk, } \\
\text { long-term and international business environments }\end{array}$ \\
\hline & Project management & Plans, controls and orients strategies, and instructs and coordinates people \\
\hline & Leadership & $\begin{array}{l}\text { Provides guidance, instruction, direction, and leadership to a group and is } \\
\text { considered charismatic among members }\end{array}$ \\
\hline & Risk tolerance & Withstands risk and overcomes failure learning from it \\
\hline \multirow{7}{*}{ 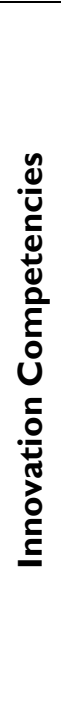 } & $\begin{array}{l}\text { Stakeholder } \\
\text { management }\end{array}$ & Demonstrates knowledge about stakeholders' needs, concerns, and desires \\
\hline & $\begin{array}{l}\text { Value/cost } \\
\text { consciousness }\end{array}$ & $\begin{array}{l}\text { Demonstrates awareness of project values and costs when creating, } \\
\text { designing, implementing and operating it }\end{array}$ \\
\hline & Curiosity for innovation & $\begin{array}{l}\text { Demonstrates curiosity to identify and to explore innovative } \\
\text { ideas/products/services which give market value }\end{array}$ \\
\hline & Problem-solving & $\begin{array}{l}\text { Identifies problems and estimates risks, evaluates the different options and } \\
\text { weights the alternatives }\end{array}$ \\
\hline & Critical thinking & $\begin{array}{l}\text { Considers issues, develops strategies to overcome obstacles, estimates their } \\
\text { risk, and implement solutions }\end{array}$ \\
\hline & Ideation & $\begin{array}{l}\text { Uses creative tools and processes, and others' advice to create functional } \\
\text { new ideas or to improve existing ideas }\end{array}$ \\
\hline & Idea implementation & $\begin{array}{l}\text { Implements activities which enable creative ideas to move from the design to } \\
\text { the marketplace }\end{array}$ \\
\hline \multirow{9}{*}{ 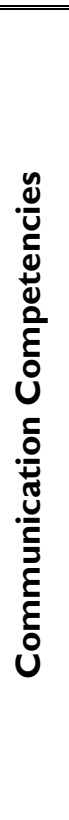 } & $\begin{array}{l}\text { Quality of presentation } \\
\text { method }\end{array}$ & $\begin{array}{l}\text { Develops presentation methods and mediums depending on topic and target } \\
\text { group }\end{array}$ \\
\hline & Presentation skills & $\begin{array}{l}\text { Gives a clear, organized and logic speech and answers questions adequately } \\
\text { and with elaboration }\end{array}$ \\
\hline & $\begin{array}{l}\text { Adaptive } \\
\text { communication style }\end{array}$ & $\begin{array}{l}\text { Communicates properly, adapting style and language to the purpose, } \\
\text { context, and environment }\end{array}$ \\
\hline & Self-confidence & $\begin{array}{l}\text { Possesses confidence in formal and informal settings and maintains eye } \\
\text { contact with the audiences }\end{array}$ \\
\hline & English language skills & Has fluency in the English language \\
\hline & Listening skills & $\begin{array}{l}\text { Listens and understand verbal messages, and consequently acts on what } \\
\text { someone says or does }\end{array}$ \\
\hline & Writing skills & $\begin{array}{l}\text { Develops a logical, accurate, detailed, and organized report/paper without } \\
\text { grammar mistakes and with accurate references }\end{array}$ \\
\hline & $\begin{array}{l}\text { Interconnection/ } \\
\text { interrelation ability }\end{array}$ & Builds and retains formal and informal relationships or networks \\
\hline & Pitching skills & Conveys and persuades audiences within a short time speech (I-3 minutes) \\
\hline
\end{tabular}




\begin{tabular}{|c|c|c|}
\hline \multirow{8}{*}{ 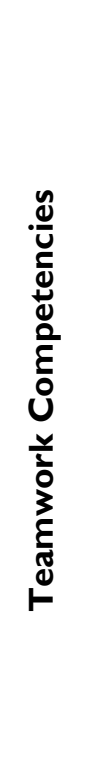 } & $\begin{array}{l}\text { Cross-cultural } \\
\text { understanding }\end{array}$ & $\begin{array}{l}\text { Understand cultural differences, recognizes their importance or benefit and } \\
\text { stimulates cooperative teamwork among people of different cultures }\end{array}$ \\
\hline & $\begin{array}{l}\text { Interdisciplinary } \\
\text { collaboration }\end{array}$ & $\begin{array}{l}\text { Collaborates with team members of engineering disciplines and of other } \\
\text { disciplines, and clients }\end{array}$ \\
\hline & Goal setting & Establishes goals balancing self and team interests \\
\hline & $\begin{array}{l}\text { Collaborative goal } \\
\text { oriented }\end{array}$ & Demonstrates a collaborative working spirit towards common goals \\
\hline & $\begin{array}{l}\text { Engagement in } \\
\text { teamwork }\end{array}$ & $\begin{array}{l}\text { Shares information and knowledge with team members and shows } \\
\text { engagement with teamwork }\end{array}$ \\
\hline & $\begin{array}{l}\text { Giving Constructive } \\
\text { feedback }\end{array}$ & Gives constructive feedback to improve team members' performance \\
\hline & Time Management & $\begin{array}{l}\text { Prioritizes, determines tasks, schedules appointments, allocates team roles } \\
\text { and meets deadlines }\end{array}$ \\
\hline & Managing conflict & $\begin{array}{l}\text { Manages conflicts between team members by stimulating healthy debates to } \\
\text { reach agreements }\end{array}$ \\
\hline \multirow{5}{*}{ 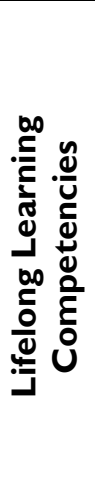 } & $\begin{array}{l}\text { Self-knowledge } \\
\text { awareness }\end{array}$ & $\begin{array}{l}\text { Possesses an awareness of strengths and weaknesses, and seeks constant } \\
\text { self-knowledge }\end{array}$ \\
\hline & $\begin{array}{l}\text { Professional role } \\
\text { awareness }\end{array}$ & $\begin{array}{l}\text { Possesses an awareness of personal and professional needs and of } \\
\text { professional engineering roles }\end{array}$ \\
\hline & $\begin{array}{l}\text { Actively seeking } \\
\text { learning }\end{array}$ & $\begin{array}{l}\text { Recognizes responsibility for own learning and seeks and develops strategies } \\
\text { and practices to increase learning }\end{array}$ \\
\hline & Autonomous work & $\begin{array}{l}\text { Works and studies with autonomy, has responsibility for tasks, manages } \\
\text { projects, and supervises people }\end{array}$ \\
\hline & $\begin{array}{l}\text { Extracurricular activity } \\
\text { participation }\end{array}$ & $\begin{array}{l}\text { Participates in volunteering activity or paid work (non-credit giving) which } \\
\text { involve responsibility }\end{array}$ \\
\hline
\end{tabular}




\section{Appendix B}

Generated rubric with four descriptive levels for each of the selected competencies.

Entrepreneurial competencies

\begin{tabular}{|c|c|c|c|c|}
\hline Criteria & Absent (Level 0) & Basic (Level I) & Advanced (Level 2) & Expert (Level 3) \\
\hline $\begin{array}{l}\text { Technology } \\
\text { benchmarking }\end{array}$ & $\begin{array}{l}\text { Not aware of market drivers, } \\
\text { emerging technologies, competitions, } \\
\text { pricing and customer needs, regulations } \\
\text { and standards }\end{array}$ & $\begin{array}{l}\text { Little awareness of market drivers, } \\
\text { emerging technologies, competitions, } \\
\text { pricing and customer needs, regulations } \\
\text { and standards }\end{array}$ & $\begin{array}{l}\text { Awareness of market drivers and } \\
\text { emerging technologies, but little } \\
\text { awareness of competitions, pricing and } \\
\text { customer needs, regulations and } \\
\text { standards }\end{array}$ & $\begin{array}{l}\text { Awareness of market drivers, } \\
\text { emerging technologies, competitions, } \\
\text { pricing and customer needs, regulations } \\
\text { and standards }\end{array}$ \\
\hline $\begin{array}{l}\text { Financial } \\
\text { awareness }\end{array}$ & $\begin{array}{l}\text { Not aware of financial capital (funding, } \\
\text { cash flow, taxes, wages, etc.) }\end{array}$ & $\begin{array}{l}\text { Little awareness of financial capital } \\
\text { (funding, cash flow, taxes, wages, etc.) }\end{array}$ & $\begin{array}{l}\text { Awareness of financial capital (funding, } \\
\text { cash flow, taxes, wages, etc.) }\end{array}$ & $\begin{array}{l}\text { Deep awareness of financial } \\
\text { capital (funding, cash flow, taxes, wages, } \\
\text { etc.) }\end{array}$ \\
\hline $\begin{array}{l}\text { Business } \\
\text { acumen }\end{array}$ & $\begin{array}{l}\text { Not able to identify business } \\
\text { opportunities nor to apply business } \\
\text { modelling and problem solving to } \\
\text { implement strategic responses }\end{array}$ & $\begin{array}{l}\text { Difficulties with identifying business } \\
\text { opportunities and applying business } \\
\text { modelling and problem solving to } \\
\text { implement strategic responses }\end{array}$ & $\begin{array}{l}\text { Identifies business opportunities but } \\
\text { has difficulties with applying business } \\
\text { modelling and problem solving to } \\
\text { implement strategic responses }\end{array}$ & $\begin{array}{l}\text { Identifies business opportunities } \\
\text { and applies business modelling and } \\
\text { problem solving to implement strategic } \\
\text { responses }\end{array}$ \\
\hline $\begin{array}{l}\text { Negotiation } \\
\text { skills }\end{array}$ & $\begin{array}{l}\text { No knowledge of basic negotiation } \\
\text { methods nor ability to negotiate in low } \\
\text { risk business environments }\end{array}$ & $\begin{array}{l}\text { Knowledge of basic negotiation } \\
\text { methods but no ability to negotiate in } \\
\text { low risk business environments }\end{array}$ & $\begin{array}{l}\text { Knowledge of negotiation methods } \\
\text { and ability to negotiate in low risk } \\
\text { business environments }\end{array}$ & $\begin{array}{l}\text { Knowledge of negotiation methods } \\
\text { and ability to negotiate in medium-high } \\
\text { risk, long-term and international business } \\
\text { environments }\end{array}$ \\
\hline $\begin{array}{c}\text { Project } \\
\text { management }\end{array}$ & $\begin{array}{l}\text { Not able to plan, monitor and } \\
\text { oriente strategies, and instruct and co- } \\
\text { ordinate subordinates }\end{array}$ & $\begin{array}{l}\text { Difficulties with planning, monitoring } \\
\text { and orienting strategies, and instructing } \\
\text { and co-ordinating people }\end{array}$ & $\begin{array}{l}\text { Plans, monitors and orients } \\
\text { strategies, but has difficulties with } \\
\text { instructing and co-ordinating people }\end{array}$ & $\begin{array}{l}\text { Plans, monitors and orients } \\
\text { strategies, and instructs and co-ordinates } \\
\text { people }\end{array}$ \\
\hline Leadership & $\begin{array}{l}\text { Not able to provide guidance, } \\
\text { instruction, direction and leadership to a } \\
\text { group }\end{array}$ & $\begin{array}{l}\text { Difficulties with providing guidance, } \\
\text { instruction, direction and leadership to a } \\
\text { group }\end{array}$ & $\begin{array}{l}\text { Provides guidance, instruction, } \\
\text { direction and leadership to a group }\end{array}$ & $\begin{array}{l}\text { Provides guidance, instruction, } \\
\text { direction and leadership to a group and } \\
\text { is considered charismatic among } \\
\text { members }\end{array}$ \\
\hline Risk tolerance & $\begin{array}{l}\text { Not able to withstand risk nor to } \\
\text { overcome failure }\end{array}$ & $\begin{array}{l}\text { Difficulties withstanding risk and } \\
\text { overcoming failure }\end{array}$ & $\begin{array}{l}\text { Withstands risk but has difficulties } \\
\text { overcoming failure }\end{array}$ & $\begin{array}{l}\text { Withdtands risk and overcomes } \\
\text { failure learning from it }\end{array}$ \\
\hline
\end{tabular}




\begin{tabular}{|c|c|c|c|c|}
\hline Criteria & Absent (Level 0) & Basic (Level I) & Advanced (Level 2) & Expert (Level 3) \\
\hline $\begin{array}{l}\text { Stakeholder } \\
\text { management }\end{array}$ & $\begin{array}{l}\text { No knowledge about stakeholders' } \\
\text { needs, concerns and desires }\end{array}$ & $\begin{array}{l}\text { Little knowledge about stakeholders' } \\
\text { needs, concerns and desires }\end{array}$ & $\begin{array}{l}\text { Knowledge about stakeholders' needs, } \\
\text { concerns and desires }\end{array}$ & $\begin{array}{l}\text { In-depth knowledge about } \\
\text { stakeholders' needs, concerns and } \\
\text { desires }\end{array}$ \\
\hline $\begin{array}{l}\text { Value/cost } \\
\text { consciousness }\end{array}$ & $\begin{array}{l}\text { Not aware of project values and costs } \\
\text { when creating, designing, implementing } \\
\text { and operating it }\end{array}$ & $\begin{array}{l}\text { Little awareness of project values } \\
\text { and costs when creating, designing, } \\
\text { implementing and operating it }\end{array}$ & $\begin{array}{l}\text { Awareness of project values and costs } \\
\text { when creating, designing, implementing } \\
\text { and operating it }\end{array}$ & Manages project values and costs \\
\hline $\begin{array}{l}\text { Curious for } \\
\text { innovation }\end{array}$ & $\begin{array}{l}\text { No curiosity to identify and to } \\
\text { explore innovative } \\
\text { ideas/products/services which give } \\
\text { market value }\end{array}$ & $\begin{array}{l}\text { Little curiosity to identify and to } \\
\text { explore innovative } \\
\text { ideas/products/services which give } \\
\text { market value }\end{array}$ & $\begin{array}{l}\text { Curious to identify and to explore } \\
\text { innovative ideas/products/services which } \\
\text { give market value }\end{array}$ & $\begin{array}{l}\text { Besides being curious, motivates } \\
\text { others to identify and explore innovative } \\
\text { ideas/products/services which give } \\
\text { market value }\end{array}$ \\
\hline $\begin{array}{l}\text { Problem } \\
\text { solving }\end{array}$ & $\begin{array}{l}\text { Not able to identify problems, } \\
\text { generate and evaluate the risk of } \\
\text { alternatives }\end{array}$ & $\begin{array}{l}\text { Difficulties with identifying problems, } \\
\text { and with generating and evaluating the } \\
\text { risk of alternatives }\end{array}$ & $\begin{array}{l}\text { Identifies problems in the real } \\
\text { world, but requires help to generate and } \\
\text { evaluate the risk of alternatives }\end{array}$ & $\begin{array}{l}\text { Identifies problems and estimates risks, } \\
\text { evaluates the different options and } \\
\text { weighs the solutions }\end{array}$ \\
\hline $\begin{array}{l}\text { Critical } \\
\text { thinking }\end{array}$ & $\begin{array}{l}\text { Not able to consider issues, } \\
\text { develop strategies to overcome } \\
\text { obstacles, estimate risks and implement } \\
\text { solutions }\end{array}$ & $\begin{array}{l}\text { Difficulties with considering issues, } \\
\text { developing stractegies to overcome } \\
\text { obstacles, estimating risks and } \\
\text { implementing solutions }\end{array}$ & $\begin{array}{l}\text { Considers issues, develops stractegies } \\
\text { to overcome obstacles, but requires help } \\
\text { to estimate risks and to implement } \\
\text { solutions }\end{array}$ & $\begin{array}{l}\text { Considers issues, develops stractegies } \\
\text { to overcome obstacles, estimates risks } \\
\text { and implement solutions }\end{array}$ \\
\hline Ideation & $\begin{array}{l}\text { Lacks of creativity tools and processes } \\
\text { and others' advices to create functional } \\
\text { new ideas or to improve existing ideas }\end{array}$ & $\begin{array}{l}\text { Uses little creative tools and processes } \\
\text { and others' advice to create functional } \\
\text { new ideas or to improve existing ideas }\end{array}$ & $\begin{array}{l}\text { Uses creativity tools and processes, } \\
\text { and others' advice to create functional } \\
\text { new ideas or to improve existing ideas }\end{array}$ & $\begin{array}{l}\text { Besides being creative, encourages } \\
\text { others to come up with new functional } \\
\text { ideas by applying their creativity and } \\
\text { innovation methods }\end{array}$ \\
\hline $\begin{array}{l}\text { Idea } \\
\text { implementation }\end{array}$ & $\begin{array}{l}\text { Not able to implement activities } \\
\text { which enable creative ideas to move } \\
\text { from the design to the marketplace }\end{array}$ & $\begin{array}{l}\text { Little ability to implement activities } \\
\text { which enable creative ideas to move } \\
\text { from the design to the marketplace }\end{array}$ & $\begin{array}{l}\text { Implements activities which enable } \\
\text { creative ideas to move from the design } \\
\text { to the marketplace }\end{array}$ & $\begin{array}{l}\text { Manages the implementation of } \\
\text { activities which enable creative ideas to } \\
\text { move from the design to the marketplace }\end{array}$ \\
\hline
\end{tabular}




\begin{tabular}{|c|c|c|c|c|}
\hline Criteria & Absent (Level 0) & Basic (Level I) & Advanced (Level 2) & Expert (Level 3) \\
\hline $\begin{array}{l}\text { Cross cultural } \\
\text { understanding }\end{array}$ & $\begin{array}{l}\text { Not able to understand cultural } \\
\text { differences, recognise their } \\
\text { importance/benefit nor stimulates } \\
\text { teamwork among different cultures }\end{array}$ & $\begin{array}{l}\text { Understands cultural differences } \\
\text { but does not recognise their importance/ } \\
\text { benefit nor stimulates teamwork among } \\
\text { different culture }\end{array}$ & $\begin{array}{l}\text { Understands cultural differences } \\
\text { and recognises their importance/ benefit } \\
\text { but does not stimulate teamwork among } \\
\text { different culture }\end{array}$ & $\begin{array}{l}\text { Understands cultural differences } \\
\text { and recognises their importance/ benefit } \\
\text { and stimulates cooperative teamwork } \\
\text { among different culture }\end{array}$ \\
\hline $\begin{array}{l}\text { Interdisciplinary } \\
\text { thinking }\end{array}$ & $\begin{array}{l}\text { Not able to collaborate with team } \\
\text { members of engineering disciplines and } \\
\text { of other disciplines, and clients }\end{array}$ & $\begin{array}{l}\text { Difficulties collaborating with team } \\
\text { members of engineering disciplines and } \\
\text { of other disciplines, and clients }\end{array}$ & $\begin{array}{l}\text { Collaborates with team members of } \\
\text { engineering disciplines, but not with } \\
\text { members of other disciplines nor clients }\end{array}$ & $\begin{array}{l}\text { Collaborates with team members of } \\
\text { engineering disciplines and of other } \\
\text { disciplines, and clients }\end{array}$ \\
\hline Goal settings & $\begin{array}{l}\text { Not able to establish goals taking } \\
\text { into account team interests }\end{array}$ & $\begin{array}{l}\text { Difficulties establishing goals taking } \\
\text { into account team interests }\end{array}$ & $\begin{array}{l}\text { Establishes small goals for the group } \\
\text { or group members considering some } \\
\text { other's perspectives }\end{array}$ & $\begin{array}{l}\text { Establishes challenging collective goals } \\
\text { balancing self and team interests }\end{array}$ \\
\hline $\begin{array}{l}\text { Collaborative } \\
\text { goal oriented }\end{array}$ & $\begin{array}{l}\text { Not able to collaborate with team } \\
\text { members to achieve common goals }\end{array}$ & $\begin{array}{l}\text { Difficulties of collaboration with } \\
\text { team members to achieve common goals }\end{array}$ & $\begin{array}{l}\text { Demonstrates a collaborative } \\
\text { working spirit towards common goals }\end{array}$ & $\begin{array}{l}\text { Collaborates, inspires and motivates } \\
\text { others to contribute to common goals } \\
\text { and to step out of comfort zones }\end{array}$ \\
\hline $\begin{array}{l}\text { Engagement in } \\
\text { team work }\end{array}$ & $\begin{array}{l}\text { Not able to share ideas and } \\
\text { knowledge with team members nor } \\
\text { show engagement with team work }\end{array}$ & $\begin{array}{l}\text { Shares some ideas and knowledge } \\
\text { with team members but shows little } \\
\text { engagement with team work }\end{array}$ & $\begin{array}{l}\text { Shares information and ideas with } \\
\text { team members and shows engagement } \\
\text { with team work }\end{array}$ & $\begin{array}{l}\text { Fosters sharing of information and } \\
\text { knowledge and encourages members to } \\
\text { be engaged with team work }\end{array}$ \\
\hline $\begin{array}{l}\text { Constructive } \\
\text { feedback }\end{array}$ & $\begin{array}{l}\text { Not able to give feedback to } \\
\text { improve team member performance } \\
\text { when asked }\end{array}$ & $\begin{array}{l}\text { Difficulties giving constructive } \\
\text { feedback to improve team member } \\
\text { performance when asked }\end{array}$ & $\begin{array}{l}\text { Gives constructive feedback to } \\
\text { improve team member performance } \\
\text { when asked }\end{array}$ & $\begin{array}{l}\text { Gives constructive feedback to } \\
\text { improve team member performance } \\
\text { even without being asked }\end{array}$ \\
\hline $\begin{array}{c}\text { Time } \\
\text { Management }\end{array}$ & $\begin{array}{l}\text { Not able to prioritize, determine } \\
\text { tasks, schedule appointments, allocate } \\
\text { team roles and meet deadlines }\end{array}$ & $\begin{array}{l}\text { Difficulties in prioritizing, } \\
\text { determining tasks, scheduling } \\
\text { appointments and meeting deadlines }\end{array}$ & $\begin{array}{l}\text { Prioritizes, determines tasks and } \\
\text { schedules appointments, but sometimes } \\
\text { has difficulty to meet deadlines }\end{array}$ & $\begin{array}{l}\text { Prioritizes, determines tasks, } \\
\text { schedules appointments, allocates team } \\
\text { roles and meets deadlines }\end{array}$ \\
\hline $\begin{array}{l}\text { Managing } \\
\text { conflict }\end{array}$ & $\begin{array}{l}\text { Not able to accept others opinions } \\
\text { generating conflicts between team } \\
\text { members }\end{array}$ & $\begin{array}{l}\text { Difficulties accepting others } \\
\text { opinions generating some conflicts } \\
\text { between team members }\end{array}$ & $\begin{array}{l}\text { Accepts and respects others } \\
\text { opinions but has difficulties managing } \\
\text { conflits between other team members }\end{array}$ & $\begin{array}{l}\text { Manages effectively conflicts } \\
\text { between team members by prompting } \\
\text { healthy debates to reach agreements }\end{array}$ \\
\hline
\end{tabular}




\begin{tabular}{|c|c|c|c|c|}
\hline Criteria & Absent (Level 0) & Basic (Level I) & Advanced (Level 2) & Expert (Level 3) \\
\hline $\begin{array}{l}\text { Quality of } \\
\text { presentation } \\
\text { method }\end{array}$ & $\begin{array}{l}\text { Not able to use a presentation } \\
\text { method and medium }\end{array}$ & $\begin{array}{l}\text { Uses the same presentation method } \\
\text { and medium without adaption to topic } \\
\text { and target group }\end{array}$ & $\begin{array}{l}\text { Uses the appropriate presentation } \\
\text { methods and medium depending on } \\
\text { topic and target group }\end{array}$ & $\begin{array}{l}\text { Develops innovative presentation } \\
\text { methods and mediums depending on } \\
\text { topic and target group }\end{array}$ \\
\hline $\begin{array}{l}\text { Presentation } \\
\text { skills }\end{array}$ & $\begin{array}{l}\text { Gives unclear, disorganized and } \\
\text { monotonous speech and does not } \\
\text { answer questions from the audience }\end{array}$ & $\begin{array}{l}\text { Gives clear, organized and logic } \\
\text { but monotonous speech and answers } \\
\text { questions rudimentary }\end{array}$ & $\begin{array}{l}\text { Gives clear, organized and logic } \\
\text { speech and answers all questions } \\
\text { adequately but without elaboration }\end{array}$ & $\begin{array}{l}\text { Gives clear, organized and logic } \\
\text { speech and answers all questions } \\
\text { adequately and with elaboration }\end{array}$ \\
\hline $\begin{array}{l}\text { Adaptive } \\
\text { communication } \\
\text { style }\end{array}$ & $\begin{array}{l}\text { Not able to communicate properly, } \\
\text { adapting style and language to the } \\
\text { purpose, context and environment }\end{array}$ & $\begin{array}{l}\text { Difficulties communicating, adapting } \\
\text { style and language to the purpose, } \\
\text { context and environment }\end{array}$ & $\begin{array}{l}\text { Communicates properly, adapting } \\
\text { style and language to the purpose, } \\
\text { context and environment }\end{array}$ & $\begin{array}{l}\text { Masters communication, adapting } \\
\text { style and language to the purpose, } \\
\text { context and environment with ease }\end{array}$ \\
\hline Self-confidence & $\begin{array}{l}\text { No confidence when talking in } \\
\text { formal or informal settings and } \\
\text { maintains no eye contact with the } \\
\text { audience }\end{array}$ & $\begin{array}{l}\text { Confidence requires development } \\
\text { when talking in informal settings and } \\
\text { little eye contact is maintained, only with } \\
\text { part of the audience }\end{array}$ & $\begin{array}{l}\text { Has confidence in talking in } \\
\text { informal settings but little in formal } \\
\text { settings, maintaining eye contact with } \\
\text { part of the audience }\end{array}$ & $\begin{array}{l}\text { Has confidence in all situations both } \\
\text { in formal and informal settings and easily } \\
\text { maintains eye contact with the whole } \\
\text { audience }\end{array}$ \\
\hline $\begin{array}{l}\text { English language } \\
\text { skills }\end{array}$ & No fluency in English language $(\mathrm{B} \mid<)$ & Basic English language fluency (B2) & $\begin{array}{l}\text { English language requires minor } \\
\text { corrections }(\mathrm{Cl})\end{array}$ & $\begin{array}{l}\text { Fluent ability in English language } \\
\text { (C2 or native) }\end{array}$ \\
\hline Listening skills & $\begin{array}{l}\text { Does not pay attention nor acts on } \\
\text { what someone says or does }\end{array}$ & $\begin{array}{l}\text { Is sometimes not paying attention } \\
\text { and not acting on what someone says or } \\
\text { does }\end{array}$ & $\begin{array}{l}\text { Listens and understands verbal } \\
\text { messages, but hardly acts on what } \\
\text { someone says or does }\end{array}$ & $\begin{array}{l}\text { Listens and understands verbal } \\
\text { messages, and consequently acts on what } \\
\text { someone says or does }\end{array}$ \\
\hline Writing skills & $\begin{array}{l}\text { Not able to develop a logical and } \\
\text { accurate report/paper and lacks } \\
\text { organization and details, and has few } \\
\text { grammar errors and missing/inaccurate } \\
\text { references }\end{array}$ & $\begin{array}{l}\text { Develops a logical and accurate } \\
\text { report/paper but lacks organization and } \\
\text { details, and has few grammar errors and } \\
\text { inaccurate references }\end{array}$ & $\begin{array}{l}\text { Develops a logical, accurate, } \\
\text { detailed, and organized report/paper } \\
\text { without grammar mistakes but with } \\
\text { missing or inaccurate references }\end{array}$ & $\begin{array}{l}\text { Develops a logical, accurate, } \\
\text { detailed, and organized report/paper } \\
\text { without grammar mistakes and with } \\
\text { accurate references }\end{array}$ \\
\hline $\begin{array}{l}\text { Interconnection/ } \\
\text { interrelation } \\
\text { ability }\end{array}$ & $\begin{array}{l}\text { Not able to understand the } \\
\text { importance of networking nor how to } \\
\text { get knowledge to interconnect and } \\
\text { create links among individuals }\end{array}$ & $\begin{array}{l}\text { Understands the importance of } \\
\text { networking but has little knowledge of } \\
\text { how to interconnect and create links } \\
\text { among individuals }\end{array}$ & $\begin{array}{l}\text { Understands the importance of } \\
\text { networking and pays attention to } \\
\text { building formal and informal relationships }\end{array}$ & $\begin{array}{l}\text { Builds and retains formal and } \\
\text { informal relationships naturally and } \\
\text { fosters others' networking }\end{array}$ \\
\hline
\end{tabular}


Not able to convey and persuade an audience with a short time speech ( $1-3 \mathrm{~min})$
Difficulties with conveying and persuading an audience with a short time speech ( I-3 min)
Able to convey and persuade an audience with a prepared short time speech (I-3 min)
Able to convey and persuade an audience with a spontaneous short time speech ( $1-3 \mathrm{~min})$

\section{Lifelong learning competencies}

\begin{tabular}{|c|c|c|c|c|}
\hline Criteria & Absent (Level 0) & Basic (Level I) & Advanced (Level 2) & Expert (Level 3) \\
\hline $\begin{array}{l}\text { Strength and } \\
\text { weakness } \\
\text { awareness }\end{array}$ & $\begin{array}{l}\text { Not aware of own strengths and } \\
\text { weaknesses and no interest in getting } \\
\text { more self-knowledge }\end{array}$ & $\begin{array}{l}\text { Little awareness of own strengths } \\
\text { and weaknesses and no interest in getting } \\
\text { more self-knowledge }\end{array}$ & $\begin{array}{l}\text { Awareness of some strengths and } \\
\text { weaknesses but no interest in getting } \\
\text { more self-knowledge }\end{array}$ & $\begin{array}{l}\text { Awareness of some strengths and } \\
\text { weaknesses and interest in getting } \\
\text { constant self-knowledge }\end{array}$ \\
\hline $\begin{array}{l}\text { Professional } \\
\text { role } \\
\text { awareness }\end{array}$ & $\begin{array}{l}\text { Not aware of personal and professional } \\
\text { needs and engineering professional roles }\end{array}$ & $\begin{array}{l}\text { Limited awareness of personal and } \\
\text { professional needs and engineering } \\
\text { professional roles }\end{array}$ & $\begin{array}{l}\text { Concrete personal and professional } \\
\text { needs but little awareness of engineering } \\
\text { professional roles }\end{array}$ & $\begin{array}{l}\text { Concrete personal and professional } \\
\text { needs and awareness of engineering } \\
\text { professional roles }\end{array}$ \\
\hline $\begin{array}{l}\text { Active } \\
\text { learning }\end{array}$ & $\begin{array}{l}\text { No responsibility for own learning } \\
\text { and no proactivity to develop learning } \\
\text { strategies and practices }\end{array}$ & $\begin{array}{l}\text { Little responsibility for own learning } \\
\text { and little proactivity to develop learning } \\
\text { strategies and practices }\end{array}$ & $\begin{array}{l}\text { Recognises responsibility for own } \\
\text { learning but has little proactivity to } \\
\text { develop learning strategies and practices }\end{array}$ & $\begin{array}{l}\text { Recognises responsibility for own } \\
\text { learning and continuously seeks and } \\
\text { develops strategies and practices to } \\
\text { improve learning process }\end{array}$ \\
\hline $\begin{array}{l}\text { Autonomous } \\
\text { work }\end{array}$ & $\begin{array}{l}\text { No autonomy when working and } \\
\text { studing, no responsibility for simple tasks, } \\
\text { and does not manage projects nor } \\
\text { supervises people }\end{array}$ & $\begin{array}{l}\text { Works and studies with little } \\
\text { autonomy, has little responsibility for } \\
\text { simple tasks, and does not manage } \\
\text { projects nor supervises people }\end{array}$ & $\begin{array}{l}\text { Works and studies with autonomy, } \\
\text { has responsibility for routine tasks, } \\
\text { manages simple projects and supervises } \\
\text { people }\end{array}$ & $\begin{array}{l}\text { Works and studies with autonomy, } \\
\text { has responsibility for complex tasks, } \\
\text { manages complex projects, and } \\
\text { supervises people }\end{array}$ \\
\hline $\begin{array}{l}\text { Non-credit } \\
\text { activity } \\
\text { participation }\end{array}$ & $\begin{array}{l}\text { No participation in volunteering } \\
\text { activity or paid work (non-credit giving) }\end{array}$ & $\begin{array}{l}\text { Participation in volunteering activity } \\
\text { or paid work (non-credit giving) with no } \\
\text { responsibility }\end{array}$ & $\begin{array}{l}\text { Participation in volunteering activity } \\
\text { or paid work (non-credit giving) with } \\
\text { limited responsibility }\end{array}$ & $\begin{array}{l}\text { Participation in volunteering activity } \\
\text { or paid work (non-credit giving) with } \\
\text { extensive responsibility }\end{array}$ \\
\hline
\end{tabular}

